\title{
Populasi Hama Wereng Batang Coklat (Nilaparvata Lugens Stal.) Dan Keragaman Serangga Predatornya Pada Padi Sawah Lahan Dataran Tinggi Di Desa Panyocokan, Kecamatan Ciwidey, Kabupaten Bandung
}

\author{
Martua Suhunan Sianipar1*, Luciana Djaya ${ }^{2}$,Entun Santosa ${ }^{2}$, RC Hidayat Soesilohadi ${ }^{3}$, Wahyu \\ Daradjat Natawigena ${ }^{2}$ dan Mochamad Ardiansyah ${ }^{4}$ \\ ${ }^{1}$ Departemen Hama dan Penyakit Tumbuhan, Fakultas Pertanian, Universitas Padjadjaran \& \\ Mahasiswa Program S-3 Ilmu Pertanian Faperta Unpad TA 2012 \\ Jl. Raya Bandung-Sumedang KM 21, Jatinangor 40600 \\ ${ }^{2}$ Departemen Hama dan Penyakit Tumbuhan, Fakultas Pertanian, Universitas Padjadjaran \\ ${ }^{3}$ Fakultas Biologi, Unversitas Gadjah Mada \\ ${ }^{4}$ Alumnus S-1 Program Studi Agroteknologi, Fakultas Pertanian, Universitas Padjadjaran \\ *Alamat korespondensi: sunandelisianipar@yahoo.com
}

\begin{abstract}
Population of Brown Plant Hopper (Nilaparvata lugens Stal.) and the Diversity of Its Natural Enemy in Highland Paddy Rice Field in the Village of Panyocokan, Ciwidey District, Bandung Regency
\end{abstract}

Brown lanthopper/BPH (Nilaparvata lugens Stal.) is a main pest of rice in the field. This research was aimed to study the population of BPH and the diversity of its natural enemy in highland paddy rice field. The survey was conducted in three paddy plots $(15 \mathrm{~m} \mathrm{x} 20 \mathrm{~m})$ located in the village of Panyocokan, Ciwidey District, Bandung Regency, West Java. The experiment was conducted in the greenhouse of the Department of Plant Pests and Diseases, Faculty of Agriculture, Universitas Padjadjaran. The samples of insects were collected systematically using yellow trap and net trap, and visually observed in each rice cluster. The number of $\mathrm{BPH}$ were recorded and accumulated each week. Fecundity, life cycle, and sex ratio of the new generation of BPH were observed in 3 replications by using 1 pair of WBC on each replication. The result showed that the population of $\mathrm{BPH}$ in the highland was below 10, which means that $\mathrm{BPH}$ population was still below the economic threshold and control threshold. Temperature, humidity, and rainfall did not significantly affect the BPH population. This was indicated by the regression analysis of each temperature $\left(\mathrm{Y}=0.557-8.167 \mathrm{x} ; \mathrm{R}^{2}=0.039 ; \mathrm{P}=0.465\right)$, humidity $\left(\mathrm{Y}=-0.077+9.112 \mathrm{x} ; \mathrm{R}^{2}=0.045 ; \mathrm{P}=\right.$ $0.428)$, and rainfall $\left(Y=-0.118+3.412 x ; R^{2}=0.136 ; P=0.159\right)$. Natural enemy diversity index tended to fluctuate widely from low to moderate. In the temperature range from $21.1^{\circ} \mathrm{C}$ to $34.8^{\circ} \mathrm{C}$, $\mathrm{BPH}$ could produce 127-207 new generation during its lifetime. BPH needed an average of 37.66 days to produce a new generation. The ratio of male to female was $1.06: 1$.

Keywords: population, brown planthopper, diversity, predator, highland paddy rice field, Ciwidey, Bandung

\section{ABSTRAK}

Hama wereng batang cklat/WBC (Nilaparvata lugens Stal.) merupakan hama utama tanaman padi. Penelitian ini bertujuan untuk mempelajari populasi WBC dan keragaman musuh alaminya pada tanaman padi sawah di dataran tinggi. Penelitian dilakukan dengan metode survei dan eksperimen. Survei dilakukan pada 3 petak lahan percobaan berukuran $15 \mathrm{mx} 20 \mathrm{~m}$ bertempat di Desa Panyocokan, Kecamatan Ciwidey, Kabupaten Bandung dan eksperimen dilakukan di rumah kaca Departemen Hama dan Penyakit Tumbuhan, Fakultas Pertanian, Universitas Padjadjaran. Metode pengambilan sampel dilakukan secara diagonal sistematis. Populasi WBC ditentukan dengan menggunakan perangkap kuning dan perangkap jaring dan dengan pengamatan langsung pada rumpun padi. Eksperimen dilakukan dengan meletakkan sepasang WBC dalam wadah, lalu diamati keperidian, siklus hidup, dan sex ratio keturunannya. WBC yang tertangkap dihitung jumlahnya dan diakumulasikan setiap minggunya. Hasil penelitian menunjukkan bahwa kepadatan populasi di 
lahan survey di bawah 10 ekor/rumpun yang artinya populasi WBC masih di bawah ambang ekonomi atau ambang kendali. Suhu, kelembaban, dan curah hujan tidak memberikan pengaruh yang signifikan terhadap populasi WBC. Hal tersebut ditunjukkan dengan analisis regresi masingmasing pada suhu $\left(Y=0,557-8,167 x ; R^{2}=0,039 ; P=0,465\right)$, kelembaban $\left(Y=-0,077+9,112 x ; R^{2}=\right.$ $0,045 ; P=0,428)$, dan curah hujan $\left(Y=-0,118+3,412 x ; R^{2}=0,136 ; P=0,159\right)$. Indeks keragaman musuh alami cenderung mengalami fluktuasi dari rendah sampai sedang. Pada kisaran suhu $21,1^{\circ} \mathrm{C}-$ $34,8^{\circ} \mathrm{C}$, hasil pengamatan keperidian menunjukkan WBC dapat menghasilkan 127-207 individu baru selama masa hidupnya. Pada pengamatan siklus hidup, WBC memerlukan rata-rata 37,66 hari sampai menghasilkan generasi baru. Pengamatan sex ratio menunjukkan perbandingan (jantan : betina) $1,06: 1$.

Kata kunci: populasi, wereng batang coklat, keragaman, predator, sawah, dataran tinggi, Ciwidey, Bandung

\section{PENDAHULUAN}

Wereng batang coklat/WBC (Nilaparvata lugens Stal.) merupakan salah satu hama pada tanaman padi. Pada awalnya, WBC merupakan hama dengan wilayah serangan yang terbatas. Namun, saat ini WBC menjadi hama utama pada tanaman padi. Hama ini dapat menyebabkan hooperburn dimana tanaman padi terlihat kering seperi terbakar. Hal tersebut terjadi karena WBC menghisap cairan sel pada batang tanaman padi (Yaherwandani dkk., 2010). Menurut Mochida (1978) dikutip Yaherwandani dkk. (2010), WBC dapat menjadi vektor penyakit kerdil rumput dan kerdil hampa yang disebabkan oleh virus pada tanaman padi.

WBC dapat bertahan sepanjang musim pada daerah tropis, tergantung terdapatnya tanaman inang yang sesuai dan kondisi iklim yang menguntungkan (Dyck \& Orlido, 1977; Mochida \& Dyck, 1977; Dyck \& Thomas, 1979; dikutip Chu \& Yang, 1985). Peningkatan populasi WBC terjadi pada kelembaban sekitar 70-80\%, suhu optimum sekitar $28^{\circ} \mathrm{C}-30^{\circ} \mathrm{C}$, intensitas cahaya rendah, pemupukan $\mathrm{N}$ tinggi, tanaman rimbun, lahan basah, dan angin lemah (Nurbaeti dkk., 2010). Pada dataran tinggi serangan WBC terjadi pada musim kemarau, sementara itu curah hujan sangat mendukung bagi perkembangan telur WBC (Romadhon, 2007). Faktor iklim baik langsung ataupun tidak langsung berpengaruh terhadap perkembangan hama. Pada umumnya WBC menyerang pada musim hujan. Ketinggian suatu tempat erat kaitannya dengan suhu dan kelembaban. Berdasarkan hasil penelitian yang dilakukan oleh Chu \& Yang (1985), estimasi suhu terendah bagi perkembangan WBC yaitu $11^{\circ} \mathrm{C}$, meskipun hanya sedikit yang dapat bertahan hidup. Dilaporkan bahwa faktor suhu dan kelembaban merupakan faktor yang dapat mendukung perkembangan populasi WBC (Yadaf et al., 2010).

Ambang ekonomi hama WBC ini yaitu jika terdapat 15 ekor WBC dalam satu rumpun padi (Pujiharti dkk., 2008). Terdapat beberapa musuh alami WBC yang bertindak sebagai predator sehingga dapat membantu mengendalikan populasi WBC, diantaranya laba-laba predator (Lycosa, Tetragnatha, Oxyopes, Callitrichia), Paederus fucipes, Ophionea sp., Cyrtorhinus lividipennis, Coccinella spp. dan Microvelia atrolineata (Kartohardjono, 2011). Pengendalian WBC dapat dilakukan dengan memanfaatkan musuh alami. Penggunaan musuh alami untuk menekan populasi WBC dapat optimal apabila kondisi lingkungan seimbang (Kartohardjono, 1988 dikutip Kartohardjono, 2011). Pada umumnya suhu minimum agar serangga dapat bertahan untuk hidup adalah $15^{\circ} \mathrm{C}$ dan maksimum $45^{\circ} \mathrm{C}$ sementara suhu optiumnya adalah $25^{\circ} \mathrm{C}$ (Ditjenbun Pertanian, 2015). Berdasarkan uraian di atas, penelitian ini bertujuan untuk mempelajari fluktuasi populasi hama WBC dan keragaman predatornya pada padi sawah lahan dataran tinggi.

\section{BAHAN DAN METODE}

Alat-alat yang digunakan adalah perangkap jaring (sweep net), perangkap perekat kuning (yellow sticky trap), label, pinset, aspirator, mikroskop, lup, botol koleksi, gelas plastik bertutup, gunting, kain kassa, hand counter, thermohygrometer digital, dan alat dokumentasi. Bahan-bahan yang digunakan adalah alkohol $70 \%$, air, dan lahan percobaan yang ditanami padi sawah varietas Ciherang.

Penelitian dilakukan dengan menggunakan metode survei dan metode eksperimen. Pengambilan sampel pada lahan dilakukan secara diagonal 
sistematis. Survei diawali dengan menyemai benih padi varietas Ciherang. Setelah berumur empat minggu padi dipindahkan ke lahan sawah dengan luas lahan $15 \mathrm{~m}^{2} \times 20 \mathrm{~m}^{2}$ sebanyak tiga lahan dengan jarak antar lahan 15 meter (Gambar 1).

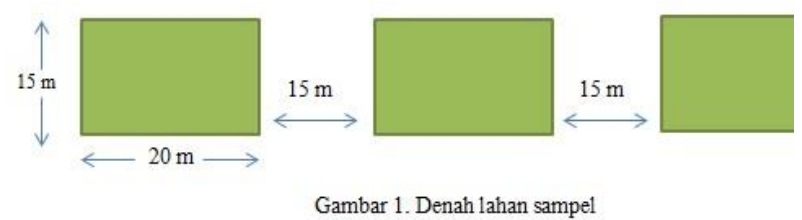

Pengambilan sampel WBC dilakukan secara manual sedangkan pengambilan sampel serangga predator dilakukan dengan menggunakan perangkap kuning dan perangkap jaring. Alat perangkap tersebut diletakkan pada lima titik diagonal. Titik pengambilan sampel terdapat pada Gambar 2.

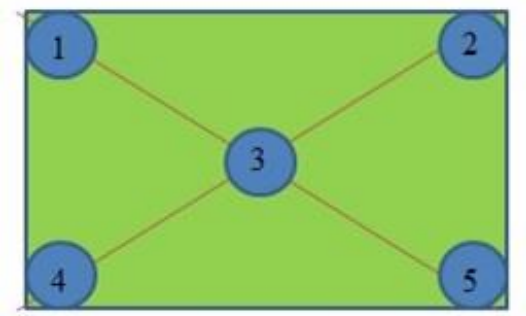

Gambar 2. Tata letak pengambilan sampel dengan menggunakan perangkap dan perhitungan secara manual.

Pengamatan secara manual dilakukan dengan cara menghitung langsung jumlah WBC pada 10 rumpun padi di setiap titik sempel. Penggunaan perangkap jaring ini dilakukan pada lima titik pengambilan sampel yang berukuran $1 \mathrm{~m}^{2}$ x $1 \mathrm{~m}^{2}$. Perangkap jaring digunakan dengan cara mengayunkannya secara dua arah sebanyak 10 kali ayunan. Pengamatan yang dilakukan meliputi populasi $\mathrm{WBC}$, serangga predator $\mathrm{WBC}$, pencatatan cuaca lahan, keperidian WBC, siklus hidup WBC, dan pengamatan sex ratio keturunan WBC. Data jumlah WBC yang telah diperoleh dianalisis dengan menggunakan Software SPSS 17. Hubungan antara lingkungan abiotik dengan populasi WBC dianalisis dengan model regresi liner sederhana menurut Gesperz (1991). Data musuh alami dianalisis dengan menggunakan perhitungan indeks keragaman menurut Shanon Weiner (Krebs, 1989) sebagai berikut:

$$
\mathrm{H}^{\prime}=-p i \ln p i
$$

$\mathrm{H}^{\prime}=$ Indeks keragaman spesies

$\mathrm{p}_{\mathrm{i}}=$ Perbandingan jumlah individu suatu jenis $\left(\mathrm{n}_{\mathrm{i}}\right)$ dengan keseluruhan jenis spesies yang terkoleksi (N)

Kriteria indeks keragaman $(\mathrm{H})$ adalah:

Keragaman jenis rendah bila $\mathrm{H}<1.5$

Keragaman jenis sedang bila $1.5 \leq \mathrm{H} \leq 3.5$

Keragaman jenis tinggi bila $\mathrm{H}>3.5$

\section{HASIL DAN PEMBAHASAN}

Data kepadatan populasi WBC secara manual pada setiap minggu terdapat pada Tabel 1 . Populasi WBC sudah muncul pada pengamatan pertama pada saat umur padi 5 MST sebanyak 2 ekor. Hal tersebut diperkirakan karena WBC merupakan hama yang dapat beradaptasi dengan cepat pada lingkungan baru, sehingga WBC dapat ditemukan meskipun tanaman padi masih berusia 5 MST dan berada di dataran tinggi. Menurut Kisimoto (1977) dikutip Baehaki \& Widiarta (2009) serangga mulai tertarik pada tanaman padi yang telah berumur 10-20 hari setelah tanam. Populasi dengan jumlah WBC terbanyak ditemukan pada pengamatan ke-4/8 MST sebanyak 11 ekor dan jumlah terkecil ditemukan pada pengamatan ke-12 sebanyak 0 ekor. Jumlah WBC mulai meningkat pada pengamatan ke-1/5 MST sampai dengan ke-4/8 MST yaitu dari 2 hingga11 ekor (Tabel 1). Hal tersebut dikarenakan terdapatnya persediaan makanan yang berlimpah serta faktor lingkungan yang mendukung. Menurut Ratna dkk. (2010) selain peletakan telur, kemampuan makan serangga juga merupakan faktor yang memengaruhi peningkatan jumlah serangga tersebut. Penurunan jumlah WBC terjadi pada pengamatan ke-5/9 MST. Hal tersebut diperkirakan karena umur tanaman padi sudah memasuki fase generatif dan sudah siap untuk dipanen, sehingga WBC tipe makroptera bermigrasi mencari tanaman inang baru. Dilaporkan bahwa populasi WBC akan menghilang setelah akhir musim tanam padi (Kuno, 1979). 
Tabel 1. Pengaruh faktor abiotik (suhu, kelembaban, dan curah hujan) terhadap hasil tangkapan WBC secara manual pada 3 lahan percobaan setiap minggunya.

\begin{tabular}{ccccc}
\hline \multirow{2}{*}{ Pengamatan } & \multicolumn{3}{c}{ Faktor abiotik } & Jumlah WBC (ekor/3 \\
\cline { 2 - 4 } 5 & Suhu $\left({ }^{\circ} \mathrm{C}\right)$ & Kelembaban $(\%)$ & Curah hujan $(\mathrm{mm})$ & petak) \\
\hline MST & 19,1 & 90 & 0 & 2 \\
7 MST & 19,6 & 86 & 0 & 3 \\
8 MST & 19,7 & 87 & 1,2 & 7 \\
9 MST & 20,9 & 80 & 0 & 11 \\
10 MST & 19,8 & 81 & 0 & 5 \\
11 MST & 18,4 & 74 & 0 & 5 \\
12 MST & 20,1 & 72 & 0 & 3 \\
13 MST & 20,3 & 82 & 1,2 & 2 \\
14 MST & 19,8 & 82 & 0 & 1 \\
15 MST & 20,2 & 86 & 20,4 & 1 \\
16 MST & 20,6 & 78 & 0 & 1 \\
17 MST & 20,3 & 78 & 0 & 0 \\
18 MST & 21,5 & 63 & 0 & 1 \\
19 MST & 17,9 & 94 & 25,6 & 0 \\
20 MST & 18,9 & 93 & 13,8 & 0 \\
Rata-rata \pm SD & 19,3 & 92 & 23,6 & 2 \\
\hline
\end{tabular}

MST = Minggu setelah tanam, SD = Standar deviasi.

WBC paling banyak didapatkan yaitu ratarata 0,022 ekor per rumpun pada pengamatan ke-4/ 8 MST (Tabel 2). Populasi WBC tersebut masih di bawah Ambang Ekonomi. Menurut Pujiharti dkk. (2008), Ambang Ekonomi WBC yaitu 15 ekor WBC pada satu rumpun padi. Bahkan Gohan (2015) dalam laporannya mengatakan jumlah WBC mencapai Ambang Ekonomi apabila ditemukan 10 ekor WBC per rumpun pada padi yang berumur 40 HST dan 20 ekor WBC per rumpun pada padi yang berumur lebih dari 40 HST.

Tabel 2. Kepadatan populasi WBC.

\begin{tabular}{|c|c|}
\hline Pengamatan & Rata-rata jumlah WBC per rumpun \pm SD \\
\hline 5 MST & $0,001 \pm 0,001$ \\
\hline $6 \mathrm{MST}$ & $0,002 \pm 0,002$ \\
\hline 7 MST & $0,005 \pm 0,004$ \\
\hline $8 \mathrm{MST}$ & $0,007 \pm 0,006$ \\
\hline 9 MST & $0,003 \pm 0,001$ \\
\hline $10 \mathrm{MST}$ & $0,003 \pm 0,001$ \\
\hline $11 \mathrm{MST}$ & $0,002 \pm 0,002$ \\
\hline 12 MST & $0,001 \pm 0,001$ \\
\hline 13 MST & $0,001 \pm 0,001$ \\
\hline 14 MST & $0,001 \pm 0,001$ \\
\hline 15 MST & $0,001 \pm 0,001$ \\
\hline $16 \mathrm{MST}$ & 0 \\
\hline 17 MST & $0,001 \pm 0,001$ \\
\hline $18 \mathrm{MST}$ & 0 \\
\hline 19 MST & 0 \\
\hline 20 MST & $0,001 \pm 0,001$ \\
\hline
\end{tabular}

$\mathrm{SD}=$ Standar deviasi. 


\section{Hubungan Jumlah WBC dengan Suhu}

Analisis regresi menunjukkan bahwa suhu tidak berpengaruh secara signifikan terhadap populasi WBC (Gambar 3). Hal tersebut ditunjukkan dengan nilai $\mathrm{Y}=0,557-8,167 \mathrm{x} ; \mathrm{R}^{2}=0,039 ; \mathrm{P}=0,465$. Persamaan regresi menunjukkan nilai signifikansi sebesar 0,510 yang berarti faktor suhu tidak berpengaruh secara signifikan terhadap peningkatan populasi WBC karena nilai signifikansi lebih besar dari 0,05. Data suhu di lapangan menunjukkan kisaran $17,9^{\circ} \mathrm{C}-21,5^{\circ} \mathrm{C}$ (Tabel 1). Nilai suhu tersebut masih kurang optimal bagi perkembangan hidup WBC karena WBC dapat tumbuh dengan baik pada suhu $28^{\circ} \mathrm{C}-30 \quad{ }^{\circ} \mathrm{C} \quad$ (Nurbaeti dkk., 2010).

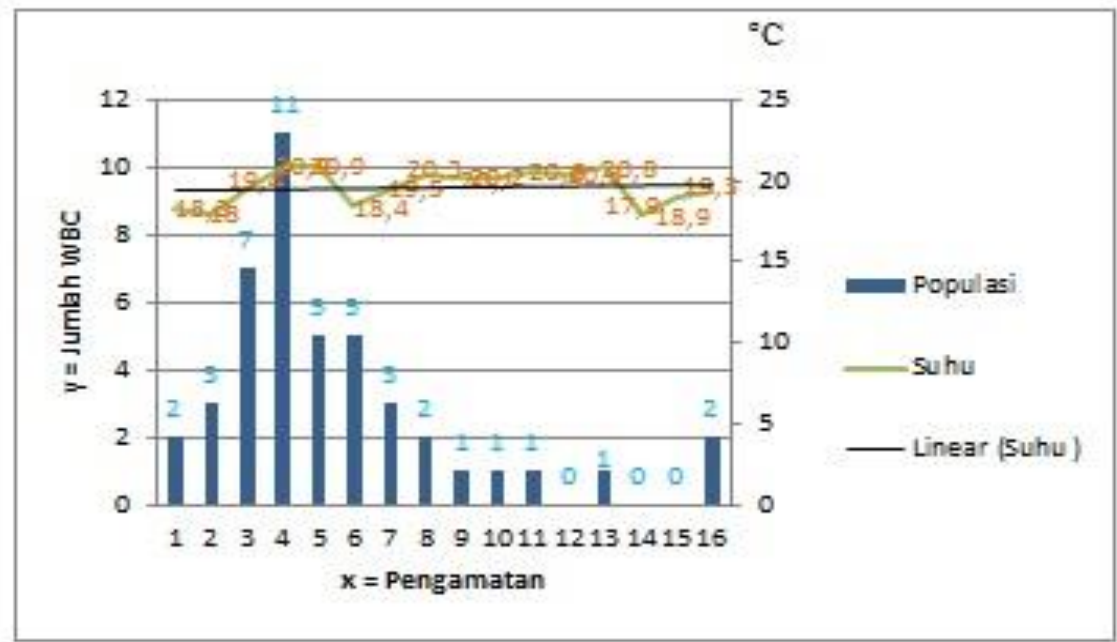

Gambar 3. Grafik peng aruh suhu terhadap populasi WBC

Hubungan Jumlah WBC dengan Kelembaban

Analisis regresi menunjukkan nilai $\mathrm{Y}=-$ $0.077+9.112 \mathrm{x} ; \mathrm{R}^{2}=0.045 ; \mathrm{P}=0.428$. Nilai regresi tersebut menunjukkan bahwa kelembaban tidak berpengaruh secara signifikan terhadap populasi WBC. Hal tersebut ditunjukkan dengan nilai signifikansi yaitu 0,624, lebih besar dari pada 0,05. Pada Gambar 4 populasi tertinggi terdapat di pengamatan ke-4/8 MST (11 ekor) dengan kelembaban $80 \%$, sedangkan penurunan populasi WBC terlihat pada pengamatan ke-14/18 MST (0 ekor) dengan kelembaban 94\%. Data kelembaban di lapangan menunjukkan kisaran 63\%-94\% (Tabel 1). Nilai kelembaban tersebut masih kurang optimal untuk peningkatan jumlah WBC karena WBC dapat berkembang dengan baik pada kelembaban 70\%80\% (Nurbaeti dkk., 2010). Selain itu, diperkirakan usia tanaman yang siap untuk dipanen sehingga WBC berpindah mencari tanaman inang lain.

\section{Hubungan Jumlah WBC dengan Curah Hujan}

Analisis regresi menunjukkan bahwa curah hujan tidak berpengaruh secara signifikan terhadap peningkatan populasi WBC di lapangan. Hal tersebut ditunjukkan dengan persamaan $\mathrm{Y}=-0,118+$ $3,412 \mathrm{x} ; \mathrm{R}^{2}=0,136 ; \mathrm{P}=0,159$. Pada awal pengamatan sudah terlihat adanya WBC pada rumpun padi. Hal tersebut diperkirakan keadaan lahan sawah masih tergenang air sehingga meskipun tidak terjadi hujan, air yang menggenangi lahan sawah dapat membantu menjaga kelembaban lingkungan hidup WBC. Menurut Piyophongkul (2013) secara tidak langsung fisiologis tanaman dan air pada tanaman padi dapat membantu membuat lingkungan yang optimal bagi WBC. Pada Gambar 5 dapat dilihat penurunan jumlah WBC terjadi pada akhir pengamatan. Hal tersebut diperkirakan karena curah hujan sudah meningkat. Curah hujan yang tinggi dapat mengurangi populasi WBC karena tetesan air hujan yang berlebihan dapat membuat serangga-serangga kecil hanyut (Sunjaya 1970 dikutip Romadhon, 2007). 


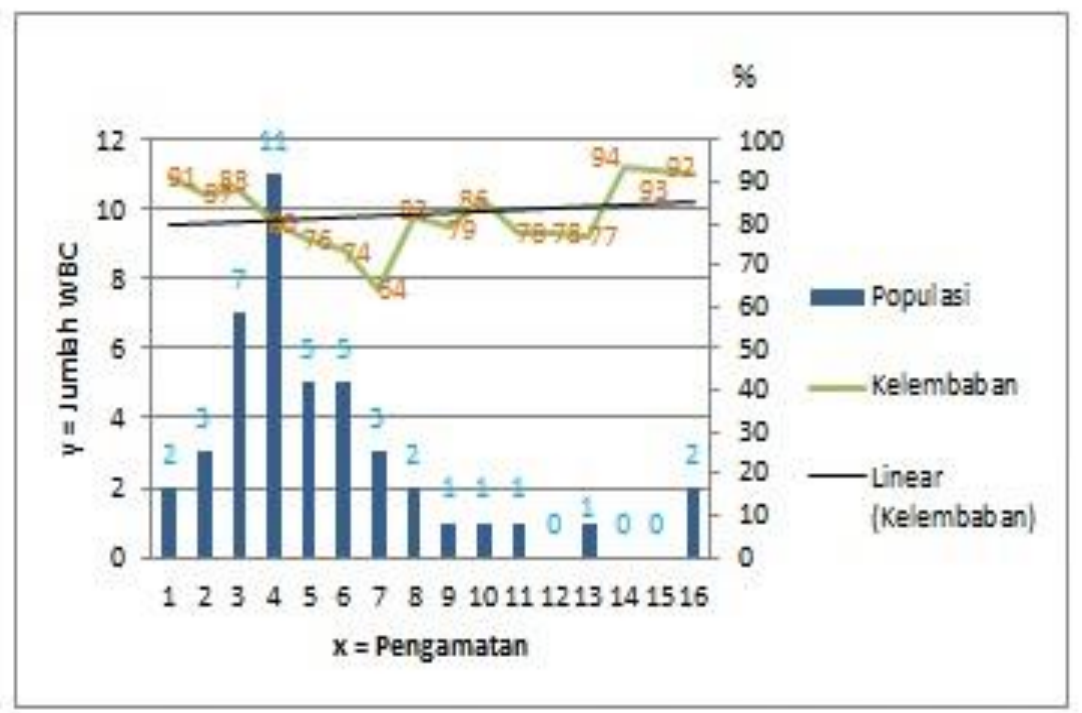

Gambar 4. Grafik pengaruh Kelembaban Terhadap Populasi WBC

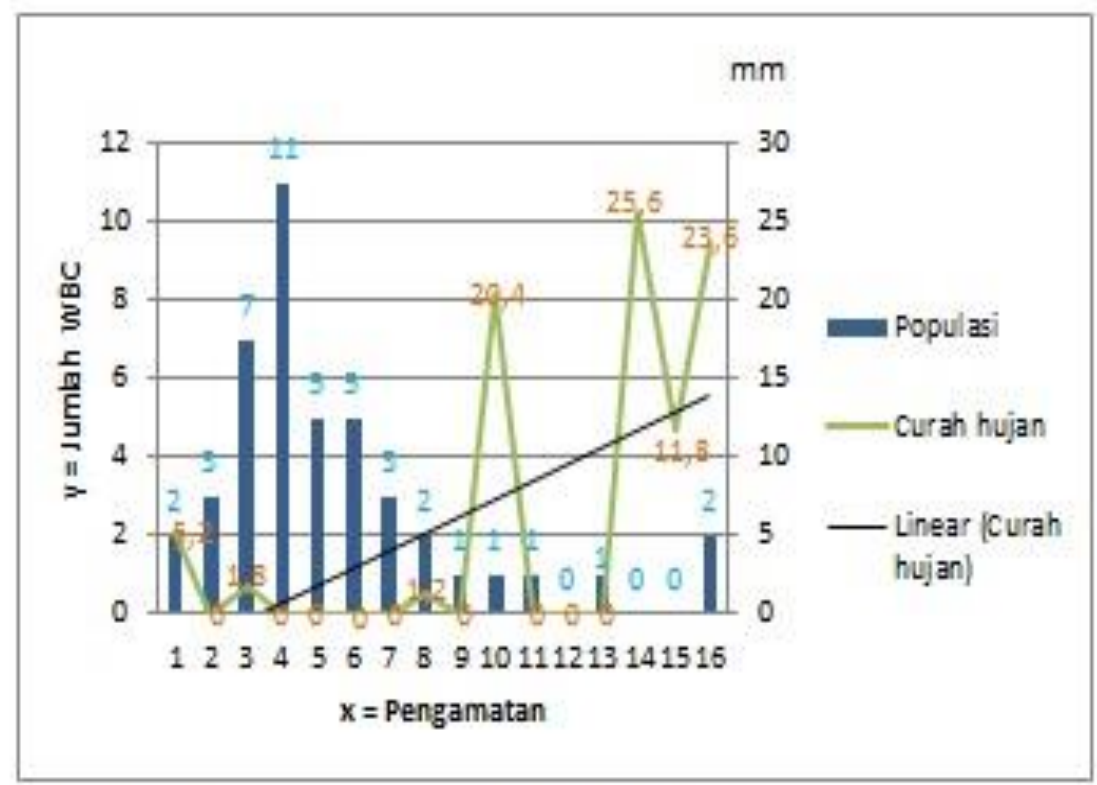

Gambar 5. Grafik pengaruh Curah Hujan Terhadap Populasi WBC

\section{Pengamatan Keperidian WBC}

Pengamatan keperidian dilakukan dengan mengamati jumlah individu baru yang dihasilkan oleh satu ekor betina WBC. Tabel 3 menunjukkan jumlah individu baru yang dihasilkan oleh satu ekor betina mencapai 127-207 ekor selama masa hidupnya. Per hari, satu ekor betina menghasilkan 3-30 ekor individu baru. Menurut Nurbaeti dkk. (2010), WBC betina dapat menghasilkan telur antara 270-902 butir yang terdiri atas 76-142 kelompok dan satu kelompok terdiri dari 3-21 butir telur. Selain itu, apabila dibiakkan di rumah kaca, betina dapat menghasilkan telur sebanyak 100-200 telur selama masa hidupnya dan jumlah telur yang dihasilkan dipengaruhi oleh umur dan periode ovipositional imago betina (Dupo \& Barrion, 2009). Telur dapat berkembang dengan baik apabila keadaan lingkungannya mendukung. Suhu di rumah kaca berkisar antara $21,1^{\circ} \mathrm{C}-34,8^{\circ} \mathrm{C}$. Sementara menurut Mochida \& Okada (1979) pada suhu $28^{\circ} \mathrm{C}-30^{\circ} \mathrm{C}$ dan suhu rendah pada malam hari diperkirakan cocok untuk menghasilkan generasi baru. 
Tabel 3. Jumlah individu baru yang dihasilkan.

\begin{tabular}{|c|c|c|c|c|c|c|}
\hline \multirow{3}{*}{ Hari ke- } & \multirow{3}{*}{ Wadah } & \multicolumn{5}{|c|}{ Jumlah individu baru (ekor) } \\
\hline & & \multicolumn{3}{|c|}{ Ulangan } & \multirow{2}{*}{ Jumlah } & \multirow{2}{*}{ Rata-rata \pm SD } \\
\hline & & 1 & 2 & 3 & & \\
\hline 9 & $\mathrm{~A}$ & 24 & 27 & 30 & 81 & $23,00 \pm 3,00$ \\
\hline 10 & B & 7 & 4 & 13 & 24 & $8,00 \pm 4,58$ \\
\hline 11 & $\mathrm{C}$ & 9 & 7 & 5 & 21 & $7,00 \pm 2,00$ \\
\hline 12 & $\mathrm{D}$ & 6 & 0 & 5 & 11 & $3,67 \pm 3,21$ \\
\hline 13 & $\mathrm{E}$ & 16 & 7 & 10 & 33 & $11,00 \pm 4,58$ \\
\hline 14 & $\mathrm{~F}$ & 10 & 11 & 18 & 39 & $13,00 \pm 4,36$ \\
\hline 15 & G & 15 & 12 & 7 & 34 & $11,33 \pm 4,04$ \\
\hline 16 & $\mathrm{H}$ & 5 & 21 & 16 & 42 & $14,00 \pm 8,19$ \\
\hline 17 & I & 7 & 0 & 5 & 12 & $4,00 \pm 3,61$ \\
\hline 18 & $\mathrm{~J}$ & 9 & 5 & 14 & 28 & $9,33 \pm 4,51$ \\
\hline 19 & $\mathrm{~K}$ & 13 & 12 & 13 & 38 & $12,67 \pm 0,58$ \\
\hline 20 & $\mathrm{~L}$ & 9 & 3 & 15 & 27 & $9,00 \pm 6,00$ \\
\hline 21 & M & 0 & 6 & 7 & 13 & $4,33 \pm 3,79$ \\
\hline 22 & $\mathrm{~N}$ & 6 & 12 & 29 & 47 & $15,67 \pm 11,93$ \\
\hline 23 & $\mathrm{O}$ & 4 & 0 & 3 & 7 & $2,33 \pm 2,08$ \\
\hline 24 & $\mathrm{P}$ & 0 & 0 & 13 & 13 & $4,33 \pm 7,51$ \\
\hline 25 & $\mathrm{Q}$ & 0 & 0 & 4 & 4 & $1,33 \pm 2,31$ \\
\hline Jumlah & & 140 & 127 & 207 & 474 & $158,00 \pm 47,76$ \\
\hline
\end{tabular}

$\mathrm{SD}=$ Standar deviasi

\section{Pengamatan Siklus Hidup}

Siklus hidup WBC terdiri dari telur, nimfa (instar 1, 2, 3, 4, dan instar 5) dan imago. Setiap fase hidup memiliki kisaran waktu untuk berubah ke fase berikutnya. Pada pengamatan siklus hidup yang dilakukan di rumah kaca, WBC memerlukan waktu rata-rata 37,66 hari untuk menghasilkan generasi baru (Tabel 4). Sementara menurut Badan Litbang Pertanian (2011), WBC menghabiskan satu kali siklus hidupnya selama 28-33 hari. Hal tersebut diperkirakan karena suhu dalam rumah kaca hanya berkisar antara $21,1^{\circ} \mathrm{C}-34,8^{\circ} \mathrm{C}$. Sementara menurut
Mochida \& Okada (1979) kisaran suhu WBC yaitu $28^{\circ} \mathrm{C}-30^{\circ} \mathrm{C}$.

Pada pengamatan siklus hidup didapatkan bahwa periode telur membutuhkan rata-rata waktu 9,26 hari, fase nimfa instar 1 sampai dengan nimfa instar 5 membutuhkan rata-rata waktu 15,58 hari, dan fase imago yaitu 12,82. Hal tersebut sesuai dengan penelitian yang dilakukan oleh Dupo \& Barrion (2009), pada iklim tropis stadia telur membutuhkan waktu 7-11 hari, stadia nimfa instar 1 sampai dengan instar 5 membutuhkan waktu 10-18 hari, dan fase imago membutuhkan waktu 18-20 hari.

Tabel 4. Lama usia stadia hidup WBC di rumah kaca.

\begin{tabular}{lcccc}
\hline \multirow{2}{*}{ Siklus Hidup } & \multicolumn{4}{c}{ Lamanya (hari) } \\
\cline { 2 - 4 } & 1 & 2 & Ulangan & \multirow{2}{*}{ Rata-rata } \\
\cline { 2 - 4 } & $8-10$ & $9-10$ & $8-11$ & 9,26 \\
Telur & $3-5$ & $3-5$ & $3-4$ & 3,82 \\
Nimfa instar 1 & $3-5$ & $3-5$ & $3-6$ & 4,27 \\
Nimfa instar 2 & $2-4$ & $2-4$ & $2-5$ & 3,17 \\
Nimfa instar 3 & $2-3$ & $2-4$ & $2-3$ & 2,16 \\
Nimfa instar 4 & $2-3$ & $2-3$ & $2-4$ & 2,16 \\
Nimfa instar 5 & $11-15$ & $11-14$ & $12-15$ & 12,82 \\
Imago & $8-45$ & $9-45$ & $8-48$ & 37,66 \\
\hline Jumlah & & & & \\
\hline
\end{tabular}

\section{Pengamatan Sex Ratio}

WBC betina dan jantan dapat dibedakan dari morfologinya. Pada WBC betina terlihat abdomen yang lebih besar dan lonjong dibandingkan dengan jantan. Menurut Dupo \& Barrion (2009) alat kelamin betina berbetuk membulat dan lebih besar dari pada alat kelamin jantan. Selain itu, 
menurutnya bentuk sayap WBC jantan lebih panjang $(3,5 \mathrm{~mm})$ dibandingkan dengan sayap WBC betina $(2,0 \mathrm{~mm})$. Dari hasil pengamatan didapatkan sex ratio keturunan jantan dan betina dalam satu masa hidupnya yaitu jantan : betina $=1,03: 1,1,05: 1$, dan 1,09:1 pada masing-masing ulangannya. Pada pengamatan sex ratio tersebut cenderung lebih banyak jantan dari pada betina, yaitu dengan ratarata sex ratio jantan : betina sebesar 1,06:1. Hal tersebut sesuai dengan penelitian Satpathi et al. (2011) yang menyebutkan dari 93 imago, sex ratio yang didapatkan adalah 1,2:1 (jantan:betina), yang dilakukan di laboratorium.

\section{Pengamatan Keragaman Predator WBC}

Berdasarkan kunci identifikasi pada buku Kalshoven (1981) dan Borror et al. (1989) didapatkan musuh alami yang berperan sebagai predator WBC, yaitu Lycosa sp., Tetragnatha sp., Oxyopes sp., Callitrichia sp., Paederusfucipes, Ophioneainterstitialis, Coccinella sp., Cyrtrohinuslividipennis, dan Microvellia sp. Pada Tabel 5 dapat dilihat bahwa musuh alami yang paling banyak ditemukan adalah Coccinella sp. (735 ekor) dengan jumlah rata-rata 245 ekor sedangkan musuh alami yang paling sedikit ditemukan adalah Microvellia sp. (5 ekor) dengan jumlah rata-rata 1,67 ekor. Coccinella sp. dan Microvellia sp. merupakan musuh alami WBC. Cocinella sp. memiliki ukuran tubuh sekitar 6-7 $\mathrm{mm}$ dan hidup di seluruh bagian tanaman. Larva predator ini memangsa secara berkelompok dengan mengunyah sasarannya (Syahrawati dkk., 2010). Microvellia sp. merupakan serangga yang hidup di permukaan air. Serangga ini menyerang wereng yang jatuh ke permukaan air secara berkelompok dan dapat memakan 4-7 wereng setiap harinya (Cybex Pertanian, 2011).

Tabel 5. Jumlah predator yang diperoleh selama pengamatan.

\begin{tabular}{llcccccc}
\hline \multicolumn{1}{c}{ Nama musuh alami } & \multicolumn{1}{c}{ Jumlah/petak } & Jumlah 3 & \multirow{2}{*}{ Rata-rata/petak } \\
\cline { 1 - 5 } \multicolumn{1}{c}{ Spesies } & \multicolumn{1}{c}{ Nama lokal } & 1 & 2 & 3 & petak & Rabala serigala \\
Lycosa sp. & Laba-laba & 15 & 14 & 12 & 41 & 13,67 \\
Tetragnatha sp. & Laba-laba rahang panjang & 12 & 23 & 21 & 56 & 18,67 \\
Oxyopes sp. & Laba-laba bermata jalang & 6 & 5 & 11 & 22 & 7,33 \\
Callitrichia sp. & Laba-laba kecil & 36 & 60 & 54 & 150 & 50,00 \\
Paederusfucipes & Tomcat & 11 & 20 & 20 & 51 & 17,00 \\
Ophioneainterstitialis & Kumbang karabid & 3 & 7 & 10 & 20 & 6,67 \\
Coccinella sp. & Kumbang kubah & 175 & 253 & 307 & 735 & 245,00 \\
Cytrohinuslividipennis & Kepik mirid & 136 & 198 & 135 & 469 & 156,33 \\
Microvellia sp. & Kepik permukaan air & 1 & 1 & 3 & 5 & 1,67 \\
\hline
\end{tabular}

Pengamatan indeks keragaman musuh alami WBC tiap petak dapat dilihat pada Gambar 6. Indeks keragaman paling tinggi yaitu 1,69 pada petak ke-3 minggu ke-3, sedangkan indeks keragaman paling kecil yaitu 0 pada petak ke-2 minggu ke-16. Hal tersebut diperkirakan pada minggu-minggu awal tanam lingkungan abiotik/iklim dan ketersediaan makanan mendukung kelangsungan hidup musuh alami. Penelitian Santosa \& Sulistyo (2007) menunjukkan musuh alami selalu terdapat pada lahan meskipun tanaman padi sudah tidak ada karena predator memangsa inang dan stadia serangga yang berbeda-beda. Apabila dilihat pada Gambar 6, indeks keragaman menunjukkan nilai yang fluktuatif pada setiap petaknya.

Berdasarkan perhitungan indeks keragaman (H) menurut Shanon Weiner (Krebs, 1989) apabila $1,5>\mathrm{H} \geq 1,5$ menunjukkan keragaman jenis rendah sampai dengan sedang. Angka indeks keragaman tersebut $(0-1,69)$ masuk pada kriteria rendah sampai dengan sedang. Dilaporkan bahwa semakin tinggi indeks keragaman maka semakin stabil ekosistem di suatu lahan. Siregar dkk. (2014) mengatakan kestabilan iklim suatu lahan akan mendukung banyaknya keanekaragaman jenis pada lahan tersebut. 


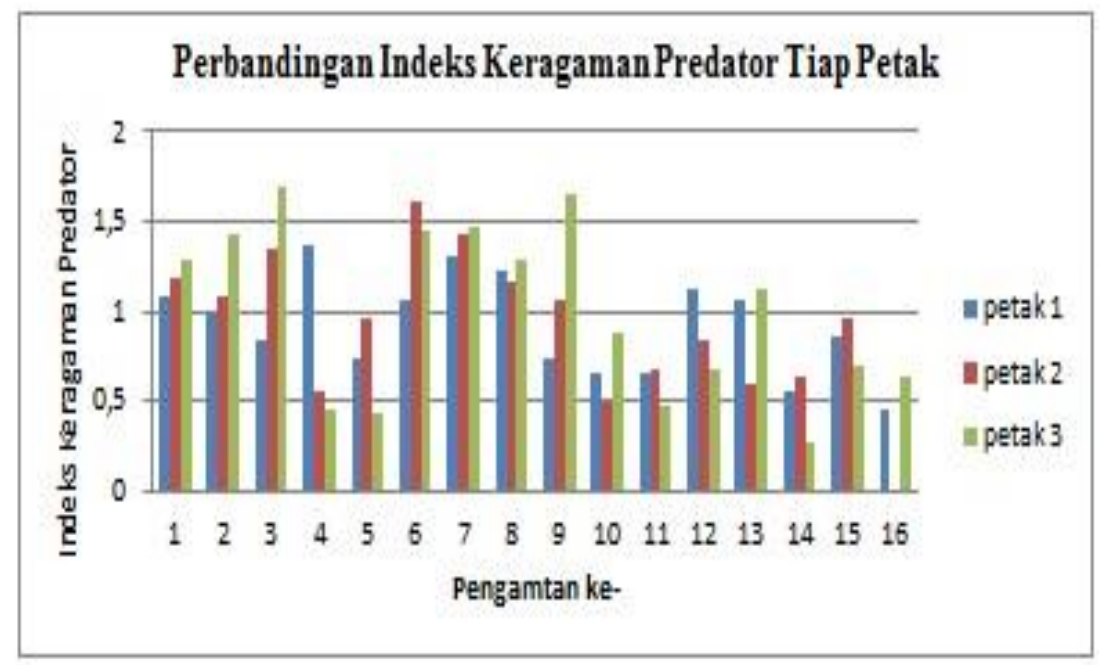

Gambar 6. Grafik perbandingan Indeks Keragaman Predator Tiap Petak

\section{SIMPULAN}

Populasi WBC meningkat pada pengamatan ke-2 (6 MST) sampai dengan ke-4(18 MST) dan mulai terjadi penurunan pada pengamatan ke-6(10 MST). Jumlah WBC selama percobaan yaitu 1-11 ekor pada 3 lahan. Faktor suhu, kelembaban, dan curah hujan tidak memberikan pengaruh yang signifikan terhadap populasi WBC, sehingga fluktuasi jumlah WBC lebih dipengaruhi oleh ketersediaan tanaman inang dan keberadaan predator di lahan. Populasi WBC yang ditemukan masih berada di bawah ambang ekonomi/ambang kendali karena kurang dari 10 ekor/rumpun. Indeks keragaman predator WBC berkisar antara rendah sampai sedang dengan nilai indeks keragaman 01,69 . Pada kisaran suhu $21,1^{\circ} \mathrm{C}-34,8^{\circ} \mathrm{C}$ di rumah kaca WBC dapat menghasilkan 127-207 individu baru dalam satu kali masa hidupnya. Siklus hidup WBC memerlukan waktu rata-rata 37,66 hari sampai menghasilkan generasi baru, dan perbandingan sex ratio WBC jantan : betina yaitu1,06 : 1 .

\section{UCAPAN TERIMA KASIH}

Pelaksanaan penelitian ini didanai dari Hibah Kompetitif Fakultas Pertanian Universitas Padjadjaran tahun 2014 berdasarkan SK Dekan Faperta No. 125/UN6.E/KEP/2014 tanggal 2 Juni 2014 dan materi serta data pada artikel ini merupakan bagian dari materi dan data disertasi Penulis pertama artikel ini. Ucapan terima kasih disampaikan kepada Dekan Faperta Unpad, Salomo Felix Sintong, Aditya Juliawan dan Moch Ardiansyah serta kepada Tim Peneliti yang telah terlibat dalam penelitian ini.

\section{DAFTAR PUSTAKA}

Badan Litbang Pertanian. 2011. Kontribusi Parameter Iklim untuk Peringatan Dini Serangan Wereng Batang Coklat/WBC (Studi kasus: Kabupaten Karawang, Subang dan Indramayu). Agroinovasi: Sinartani. Edisi 20-26 Juli 2011 No. 3415 Tahun XLI. $11 \mathrm{hlm}$.

Baehaki, SE dan IN Widiarta. 2009. Hama Wereng dan Cara Pengendaliannya Pada Tanaman Padi. Balai Besar Penelitian Tanaman Padi. Hlm. 349-350.

Borror, DJ, CA Triplehorn dan NF Jhonson. 1989. Pengenalan Pelajaran Serangga Edisi Keenam. Gajah Mada University Press. Yogyakarta. Indonesia. Hlm. 367-368

Chu, YI and PS Yang. 1985. Ecology of the Brown Planthopper (Nilaparvata lugens Stal.) during the Winter Season in Taiwan. Department of Pathology and Entomology National Taiwan University. Pp. 23-34.

Cybex Pertanian. 2011. Predator-Kepinding Air (Jenis yang Membantu Petani). Tersedia online pada http:/cybex.pertanian.go.id/materipenyulu han/detail/3343. Diakses tanggal 19 Juni 2015.

Ditjenbun Pertanian. 2015. Faktor Pendukung Penyebaran Serangga di Lapangan. Tersedia online pada http://ditjenbun.pertanian.go.id/bbpptpamb on/berita-236-faktor-pendukung- 
penyebaran-serangga-di-lapangan-.html. Diakses tanggal 30 Juni 2015.

Dupo, ALB and AT Barrion. 2009. Taxonomy and General Biology of Delphacid Planthoppers in Rice Agroecosytems. Pp 3-156 In Heong KL and Hardy B (editors). Planthoppers: New Threats to Thesustainability of Intensive Rice Production Systems in Asia. Los Baños (Philippines): International Rice Research Institute. Pp. 126-128.

Dyck, V A, BC Misra, S Alum, CN Chen, CY Hsieh and RS Rejesus. 1979. Ecology of the Brown Planthopper in The Tropics: Brown Planthopper-Threat to Rice Production in Asia. International Rice Research Institute. $70 \mathrm{p}$.

Gaspersz, V. 1991. Metode Perancangan Percobaan. Armico. Bandung.

Gohan. 2015. Pengendalian Hama Terpadu Wereng Batang Coklat. Tersedia online pada http://lampung.litbang.pertanian.go.id/ind/i ndex.php?option=com_content\&view=articl e\&id=476:pengendalian-hamaterpaduwereng-batang-coklat. Diaksse tanggal 11 Juni 2015.

Kartohardjono, A. 2011. Penggunaan musuh alami sebagai komponen pengendalian hama padi berbasis ekologi. Pengembangan Inovasi Pertanian. 4 (1): 29-46.

Klashoven, LGE. 1981. The Pests of Crops in Indonesia. PT Ichtiar Baru-Van Hove. Jakarta. Hlm. 131-134.

Krebs, CJ. 1989. Ecological Methodology. Harper and Row Publisher. New York. Pp. 377-378.

Kuno, E. 1979. Ecology of the Brown Planthopper in Temperate Regions: Threat to Rice Production in Asia. International Rice Research Institute. 46 p.

Mochida, O and T Okada. 1979. Taxonomy and biology of Nilaparvata lugens (Hom., Delphacidae) in Brown Planthopper: Threat to Rice Production in Asia. International Rice Research Institute. Los Banos, Phillipines. Pp. 21-43.

Nurbaeti, B, IGP Alit Diratmaja dan S Putra. 2010. Hama Wereng Coklat (Nilaparvata lugens Stal.) dan Pengendaliannya. Balai Pengkajian Teknologi Pertanian. Jawa Barat. Hlm. 4-29.
Piyaphongkul, J. 2013. Effects of Thermal Stress on the Brown Planthopper Nilaparvata lugens (Stal). Thesis. School of Biosciences. University of Birmingham. Pp. 8-27.

Pujiharti, Y, J Barus dan B Wijayanto. 2008. Teknologi Budidaya Padi. Balai Besar Pengkajian dan Pengembangan Teknologi Pertanian. Lampung. $16 \mathrm{hlm}$.

Ratna, ES, A Kartoharjono dan Rahmini. 2010. Respon Morfo-Fisiologi Wereng Batang Cokelat Biotipe1, 2, 3 terhadap 6 Varietas Padi Tahan dan 1 Varietas Rentan untuk Mendapatkan Varietas Durable Resistance. Ringkasan Eksekutif Hasil-Hasil Penelitian. Kerjasama Kemitraan Penelitian Pertanian dengan Perguruan Tinggi (KKP3T). 2 hlm.

Romadhon, S. 2007. Anal sis Tingkat Serangan Wereng Batang Coklat (Nilaparvata lugens Stal.) Berdasarkan Faktor Iklim(Studi Kasus: 10 Kabupaten Endemik di Provinsi Jawa Barat) [Skripsi]. Departemen Geofisika dan Meteorologi. Fakultas Matematika dan Ilmu Pengetahuan Alam. Institut Pertanian bogor. Bogor. Hlm. 4-24.

Santosa, SJ dan J Sulistyo. 2007. Peranan Musuh Alami Hama Utama Padi Pada Ekosistim Sawah. Innofarm: Jurnal Inovasi Pertanian. 6 (1): 1-10.

Satpathi, CR, G Katti and YG Prasad. 2011. Effect of Seasonal Variation in Life Table of Brown Plant Hopper Nilaparvata lugens Stal. on Rice Plant in Eastern India. Middle-East Journal of Scientific Research. 10 (3): 370373.

Siregar, AS, D Bakti F dan Zahara. 2014. Keanekaragaman Jenis Serangga di Berbagai Tipe Lahan Sawah. Jurnal Online Agroekoteknologi. 2 (4): 1640-1647.

Syahrawati, M, M Busniah dan N Nelly. 2010. Sosialisasi Teknik Konservasi Musuh Alami Wereng Coklat (Nilaparvata lugens) pada Petani Perempuan. Lembaga Pengabdian kepada Masyarakat Universitas Andalas. 9 hlm.

Yadaf, DS, S Chander and K Selvaraj. 2010. Agroecological Zoning of Brown Planthopper [Nilaparvata lugens (Stal)] incidence on rice (Oryza sativa L.). Journal of Scientific \& Industrial Research. 69: 818-822. 
Yaherwandi, Reflinaldon dan A Rahmadani. 2010.

Biologi Nilaparvata lugens Stall

(Homoptera: Delphacidae) pada Empat
Varietas Tanaman Padi (Oryza sativa L.). Fakultas Pertanian. Universitas Hasanudin. Padang. Sumatra Barat. 9-17 hlm. 